\title{
Employee Performance of Work Training Center in Banda Aceh \\ (A Study of Government Regulation's Implementation Number 46 of 2011 concerming Performance Assessment of Civil Servants)
}

\author{
Lidya $\operatorname{Tasza}^{1}$, Ismail ${ }^{2}$ \\ ${ }^{1,2}$ Universitas Iskandar Muda, Aceh, Indonesia \\ ismailfisipol.unida@gmail.com
}

\section{Abstract}

This study aims to determine and analyze the assessment of State Civil Apparatus (ASN) work targets on Work Training Center (BLK) in Banda Aceh as well as to find out and analyze the work behavior of Work Training Center (BLK) in Banda Aceh in preparing a professional workforce. This study uses a qualitative approach with the type of descriptive research. Data collection is done through observation, interviews and document studies. The conclusion of the research shows that the work targets of employees at the Work Training Center $(B L K)$ in Banda Aceh related to quantity, quality, time and cost indicate that the quantity of work is very much and does not reduce quality. While the time spent completing these activities varies greatly and depends on the program itself. Furthermore, related to the costs required to complete a job, it really depends on the proposal and also a realistic study. Then the Behavior of Employees at the Work Training Center (BLK) in Banda Aceh in conducting service orientation to the community and other parties by promoting equality, means that there is no difference in services provided to the community and also to other institutions.
Keywords

employee performance; work target; work behavior

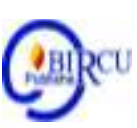

\section{Introduction}

The State Civil Apparatus (ASN) or Employee is the basis for implementing the government system. This was as stated by Musanef (2016) that "The existence of ASN is essentially the backbone of the government in carrying out national development". Therefore, ASN is expected to be able to mobilize and launch government tasks in development, including serving the public. In accordance with its main function as the main executor of this country's government, the civil servants are required to have a high work ethic and time discipline. This is certainly a challenge that must be answered by all civil servants in this country. Not only in the top ranks, but also in all staff to the lowest level. This is based on the idea that however it cannot be denied, although it is not the only determining factor, the progress of this country depends on the performance of government agencies, in this case the civil servants themselves.

Based on Government Regulation Number 46 of 2011 Concerning Evaluation of Civil Servant Work Performance or now known as ASN, its performance can be assessed from several aspects, namely work objectives and employee behavior. Work targets show how the quantity, quality, time and costs incurred and produced from employees. Whereas relating to employee behavior shows employee attitudes such as service orientation, integration, commitment, and discipline. Civil servants who have good work targets will maintain the quantity of work with the amount, results and time of work carried out; 
maintain work quality, process quality, and environmental quality; good time at work; and efficient work without costing a lot of money. In addition to the work objectives of each civil servant must also have the behavior as a good employee such as having a service orientation to the community, superiors / colleagues, and work units in other agencies having the integrity of values, norms and organizational ethics at work.

In terms of improving employee performance, the leader factor becomes dominant that makes progress and setbacks of an organization, because the ability and inability to lead has implications for the performance of subordinates or employees. This is in accordance with the opinion of Thoha (2014) states that "An organization will succeed or even fail is largely determined by leadership factors". In order to improve the performance of the State Civil Apparatus, the leadership needs to play an optimal role so that employees can carry out their duties and are responsible for their work. Moreover, coupled with compensation, of course it has very implications for the performance of employees of the State Civil Apparatus (ASN). To be able to improve employee performance, especially at the Work Training Center (BLK) leaders must be able to foster good cooperation, direct and encourage subordinates to work.

To realize the work discipline of the State Civil Apparatus, sanctions or punishment are needed. But that is not enough, but also the leadership must pay attention to the level of welfare of its employees as related to work relations or facilities provided. This can trigger employees to increase their loyalty in carrying out responsibilities in an organization.

Based on preliminary observations made by researchers at the research location, there are a number of things that are a problem of employee performance at Work Training Center (BLK) in Banda Aceh. Who then go home, and there are also employees who enter the office just sitting around, and there are employees who do not have the skills to use a computer such as old employees and who will enter retirement.

The issuance of Government Regulation No. 46 of 2011 which regulates work performance appraisal based on employee work target and employee behavior is expected to motivate civil servants in improving work performance. Employee performance has its own consequences for improving performance in government organizations where he works. If employees have good performance, the organization also has good performance. In this study, researchers wanted to identify several dominant factors that were suspected to have contributed positively or negatively to employee performance at Work Training Center (BLK) in Banda Aceh.

Based on the description above, the researcher is interested in conducting an in-depth study of "Employee Performance of Work Training Center in Banda Aceh (A Study of Government Regulation's Implementation Number 46 of 2011 concerning Performance Assessment of Civil Servants)".

\section{Review of Literature}

\subsection{Theory of Public Policy Implementation}

The implementation of policies in principle is a way for a policy to achieve its objectives. According to Agustino (2013) implementation is "A dynamic process, whereby the implementer of the policy carries out an activity or activity, so that in the end it will get a result that is in accordance with the goals or objectives of the policy itself". According to Abidin (2014) public policy is "Decisions made by the government or institutions authorized to solve problems or realize the desired goals of society".

Whereas in the opinion of Thomas (2014) public policy is "The efforts chosen by the government to do or not to take place in the form of targets or objectives of government 
programs. Meanwhile, according to Dadang in Agustino (2013) public policy as "A series of actions proposed by a person, group or government in a particular environment, with threats and opportunities that exist in an institution". The proposed policy is intended to exploit the potential while overcoming existing obstacles in order to achieve certain goals.

Meanwhile according to Abidin (2014) policy implementation is

"A very important step in the policy process. Without implementation, a policy is just a document that is not meaningful in social life. Therefore, a policy program must implemented so that it has the desired impact or purpose ". In addition, Nugroho (2016) explains that the clarity of the meaning of policy implementation is "A way for a policy to achieve its objectives. To implement public policy, there are two choices of steps available, namely directly implementing in the form of a program or through the formulation of policy degrees or derivatives of the public policy ".

Based on several concepts that have been put forward by experts, the researcher can conclude that, the implementation of public policy is a step in the implementation phase of a policy to achieve the stated goals that produce an impact from the policy process the. One of the implementation of the policy is the assessment of work performance set in Government Regulation Number 46 of 2011. The performance evaluation indicators according to Government Regulation Number 46 of 2011 concerning Employee Performance Evaluation are:

a. Employee Work Targets (SKP)

The SKP contains the job assignment activities and targets that must be achieved within a tangible and measurable evaluation period. SKP assessment includes aspects:

1) Quantity;

2) Quality;

3) Time;

4) Costs.

b. Work behavior, including aspects of:

1) Service Orientation;

2) Integrity;

3) Commitment;

4) Discipline;

5) Cooperation;

6) Leadership.

\subsection{Performance Theory}

The principle of performance appraisal is a way of measuring the contributions of individuals in the agency made to the organization. The importance of performance appraisal is concerned with determining the level of individual contribution or performance expressed in the completion of the tasks for which it is responsible.

According to Chung in Sulistiyani (2013) performance appraisal is "A way to measure employee contributions to organizations. By knowing the employee's contribution, it can then be used as an effort to compile an award and compensation program. "Performance appraisal according to Dessler (2013) is "Evaluating employee performance now and / or in the past relative to his performance standards". Mangkunegara defines performance as "Quality and quantity work results achieved by an employee in carrying out their duties in accordance with the responsibilities given to him".

Simamora (2014) explains performance appraisal is "The process used by organizations to evaluate the work performance of individual employees. Whereas Hasibuan (2013), 
performance appraisal is "Assessing the ratio of real work results with quality and quantity standards produced by each employee". Usman (2014) states that "Performance is the result of work and progress achieved by someone in the field of tasks. Performance equals work performance or performance ". Performance is a translation of performance which is often interpreted as a performance or achievement.

Bangun (2014) explains that in order to facilitate employee performance appraisal, work standards must be clearly measured and understood. A job can be measured through:

a. Amount of work; this dimension shows the amount of work that is

b. individual or group produced as requirements that become work standards;

c. Quality of work; jobs have quality standards that must be adjusted by employees to work according to the provisions;

d. Punctuality; each job has different characteristics for certain types of work to be completed on time because it has a dependency on other jobs;

e. Presence; all certain types of work require employee attendance to do so in accordance with the specified time. Employee Performance

f. determined by the level of attendance of employees in doing it;

g. Cooperative ability; not all work can be completed by one person. For certain types of work may have to be completed by two or more people, so it requires cooperation.

There are 5 (five) indicators in assessing individual performance in organizations according to Mondy in T (2014), namely:

a. Time standards;

b. Productivity standards;

c. Cost standards;

d. Quality standards;

e. Behavioral standards.

The objectives of performance appraisal as stated by Rivai (2013) include:

a. To find out the level of employee performance;

b. Providing equal compensation, as a source of information for decision making relating to salary, wages, incentives, compensation and various other rewards;

c. HR development in reassignments such as holding transfers or transfers, promotions or promotions, education and training;

d. Increase motivation;

e. Tools for maintaining performance levels;

f. Tools to help and encourage employees to take initiatives in order to improve performance.

While the objectives of performance evaluation according to Sulistiyani (2013) include:

a. Know the goals and objectives of management and employees;

b. Motivate employees to improve their performance;

c. Distributing rewards from organizations that can include salary increases and fair promotions;

d. Carry out personnel management research.

Based on the performance appraisal objectives above, one of the objectives performance appraisal, which is as a reference in matching rewards, as a source of information for decision making relating to salary, wages, incentives, compensation and various other benefits. With the performance appraisal, the organization can find out and calculate the amount of compensation that must be received by employees for the performance achieved. 


\subsection{Concept of Employee Work Target}

Employee Work Targets, hereinafter abbreviated as SKP are work plans and targets to be achieved by a civil servant. Employee Work Targets (SKP) are employee work targets that are included in one of the elements in the Civil Service Work Performance Appraisal set in Government Regulation Number 46 of 2011. Performance appraisals are assessments made by superiors to subordinates. How to determine the target quantity in work that cannot be predicted or its output from others is by considering the amount of output that entered in previous years. How to assess the quality aspects of a job / activity is by referring to the parameters in the Head of BKN Regulation No. 1 of 2013.

In Government Regulation Number 46 of 2011, every civil servant is required to prepare SKP based on the agency's RKT. In preparing SKP, the following matters must be considered:

a. Clear. The activities carried out must be clearly described.

b. Can be measured. Activities carried out must be measured in quantity in terms of numbers such as the number of units, the number of results, etc. as well as quality such as perfect work, no errors, no revisions and satisfactory service to the community, and others.

c. Relevant. Activities carried out must be based on the scope of the duties of each position.

d. Achievable. Activities undertaken must be adjusted to the ability of civil servants.

e. Has a target time. The activities undertaken must be timed.

In the work performance appraisal system, each civil servant is obliged to prepare a SKP as a draft implementation of the job assignment activities, in accordance with the details of the duties, responsibilities and authorities, which have generally been determined in the organizational structure and work procedures. The SKP is prepared and stipulated as an operational plan for the implementation of the Position Task Activities, with reference to the organization's Strategic Plan (Renstra) and Annual Work Plan (Renja), which contains what activities will be carried out, what results will be achieved, what will be produced and when must be finished. Each Job Position Activities that will be carried out, the target as a result of work must be realized, taking into account the aspects of quantity / output, quality, time and can be accompanied by costs.

\subsection{Behavior Theory}

There are four indicators that can be used to determine work behavior according to Griffiths (2014), namely:

a. Social relationships. A worker must have good social relations with other workers, where each worker must supervise colleagues to act in the right direction and warn if there are mistakes.

b. Vocational skills (vocational skills). Expertise that someone has in accordance with their work, for example someone with cooking skills is suitable to become a Chef.

c. Work motivation (work motivation). Willingness to work to achieve certain goals such as physiological needs, security, love, self-esteem, and self-actualization.

d. Initiative-confidence. Namely in good work behavior must foster full confidence and take the initiative that all work can be carried out in accordance with the existing job description.

According to Government Regulation No. 6 of 2011 work behavior is every behavior, attitude or action taken by a civil servant or does not do something that should be done in accordance with statutory provisions. The assessment of work behavior includes aspects of: 
a. Service orientation. The attitudes and behavior of civil servants in providing the best service to those served include among others the community, superiors, co-workers, related work units, and / or other agencies.

a. Integrity. The ability to act in accordance with values, norms and ethics in organizations.

b. Commitment. Willingness and ability to harmonize the attitudes and actions of civil servants to achieve organizational goals by prioritizing the interests of themselves, individuals, and / or groups.

c. Discipline. The ability of civil servants to obey their obligations and avoid the prohibitions specified in statutory regulations and / or official regulations which if not obeyed or violated are disciplined.

d. Cooperation. The willingness and ability of civil servants to cooperate with colleagues and other agencies in completing a given task and responsibility, so as to achieve maximum efficiency and effectiveness.

e. Leadership. The ability and willingness of civil servants to motivate and influence subordinates or others related to their field of work in order to achieve organizational goals.

The assessment of work behavior is carried out through observation by officials assessors of civil servants according to specified criteria. Appraisal officials in assessing civil servant work behavior may consider input from other appraisal officials at the same level as their respective work units. The value of work behavior can be given as high as 100 (one hundred).

\section{Research Methods}

This research was conducted at Work Training Center (BLK) in Banda Aceh located on Jalan Ksatria Komplek Geuceu 23239, Banda Aceh. The reason researchers took the location was:

1. Ease of obtaining data access;

2. The location is easy to reach;

3 . The theme that the researchers adopted is at the location.

The basic objective of determining the location is to see how the performance of the Work Training Center (BLK) in Banda Aceh in carrying out their main duties and functions in accordance with their position or position. In this case the researchers used a descriptive qualitative approach to gain understanding in accordance with the objectives of the study.

According to Moleong (2014) qualitative research is "Research that intends to understand phenomena about what is experienced by research subjects such as behavior, perception, motivation, actions, etc., holistically, and by means of descriptions in the form of words and languages, in a natural context and by utilizing various natural methods ". Meanwhile, according to Faisal (2014) explains descriptive qualitative research, namely: Intended for exploration and clarification of a phenomenon or social reality, by describing a number of variables relating to the problem and unit under study. This type of research does not concern the relationship between existing variables, it is not intended to attract the generation that explains the variables that cause a symptom or social reality. Therefore, in a descriptive study, do not use and do not test hypotheses.

Data sources used in this study consisted of:

a. Primary data source. Primary data is data obtained from original sources at the research location through the informants used as informants. There are ways to get primary data by observation, interview and documentation. According to Indriantoro in Mulyana (2014) 
"Primary data is a source of research data obtained directly from the original source (not through an intermediary)".

b. Secondary data source. Secondary data is data that has been available in advance through various existing references. According to Indriantoro in Sugiyono (2016 secondary data is "Sources of research data obtained indirectly, deliver through intermediary media or obtained and recorded by other parties".

While the determination of informants is done by purposive sampling, according to Sugiyono (2016 :) purposive sampling, namely "the technique of determining the informants with certain considerations". Determination of informants by purposive sampling is done with the assumption that the selected informants understand the problem under study and can provide information and data related to the research objectives.

The informants included in this study consisted of 5 (five) people. For more details can be seen in table 1 below.

Table 1. Research Informant

\begin{tabular}{|l|l|l|}
\hline No. & Informants & Total \\
\hline 1. & Administrative Section Staff & 3 \\
\hline 2. & Administration Section Staff & 1 \\
\hline 3. & Empowerment Staff & 1 \\
\hline \multicolumn{2}{|l|}{ Total } & 5 \\
\hline
\end{tabular}

Then as for the data collection techniques used in this study through observation, interviews, and documentation. According to Hamzah (2013) observation is "The method of collecting data by observing the behavior of a person or group of people in doing a job. According to Tatag (2014) observation is "Efforts to record all events and activities that occur during the corrective action took place with or without the aid tool". According to Suparlan in Bungin (2014: 95) suggested eight things that must be considered by researchers when making observations include:

a. Space and time;

b. Perpetrators;

c. Activity;

d. Objects or tools;

e. Time;

f. Event;

g. Aim; and

h. Feeling.

Furthermore, in the context of data collection researchers also conducted interviews with various informants to obtain information and input in accordance with the objectives and research focus. Researchers conducted structured interviews so as to prepare the research instrument in the form of written questions. In this study, researchers used a type of semistructured interview, which is an interview that initially uses structured questions, then one by one deepened and developed in search of further information. To obtain accurate data information needed data collection techniques that are considered appropriate, researchers act as the first instrument (key instrument) that integrates with natural data sources. Then documentation analysis is a data collection technique that is not directly addressed to the research subject. Documents examined can take a variety of forms, not just official documents. The documents needed in this research are written material related to the research title from various sources. 


\section{Discussion}

Work Training Center (BLK) is a training institute designed and formed by the government to address several issues related to employment and unemployment as well as employment problems in the country, especially for children who have dropped out of school who cannot continue because of economic factors. For children who find it difficult to find employment after completing education, then they are given the opportunity to attend training at Work Training Center (BLK) in various fields of interest. After attending the training, with the available skills it is expected to be able to work independently.

The Government of Aceh pays great attention to tackling the problem of unemployment. In the Aceh Medium-Term Development Plan 2017-2022, increasing access to employment opportunities and increasing the expertise and competitiveness of the workforce are defined as activities that are part of the main poverty alleviation program in Aceh. Work Training Center (BLK) are institutions that play a strategic role in tackling the problem of unemployment and increasing labor productivity. It is hoped that the trainings held by these government institutions will equip young people to have adequate knowledge and skills in facing the increasingly competitive labor market today.

Work Training Center (BLK) play a significant role in opening up employment opportunities for unemployed community members. Through its programs and activities, BLK is expected to be able to train community members to become reliable, skilled and ready-to-use workers. The training held by BLK in turn is expected to help unemployed community members to find work or even be able to create their own jobs.

Vocational and training programs at Work Training Center (BLK) in Banda Aceh consist of twelve majors. For more details about the existing vocational training programs and at Work Training Center (BLK) in Banda Aceh each year can be seen in table below.

Table 2. Vocational and Training Programs at BLK Banda Aceh in 2020

\begin{tabular}{|c|l|c|c|}
\hline No & \multicolumn{1}{|c|}{ Vocational and Training Programs } & $\begin{array}{c}\text { Capacity / } \\
\text { Amount }\end{array}$ & $\begin{array}{c}\text { Instructor / } \\
\text { Amount }\end{array}$ \\
\hline 1 & Vocational Manufacturing Engineering & 96 & 1 \\
\hline 2 & Vocational Las Engineering & 96 & 1 \\
\hline 3 & Vocational Automotive Engineering & 160 & 3 \\
\hline 4 & Vocational Electrical Engineering & 192 & 2 \\
\hline 5 & Vocational Electronics Engineering & 128 & 2 \\
\hline 6 & Vocational Refrigeration & 64 & 2 \\
\hline 7 & Vocational Building Engineering & 176 & 2 \\
\hline 8 & Vocational Business and Management & 192 & 1 \\
\hline 9 & Vocational Information and Communication Technology & 288 & 2 \\
\hline 10 & Vocational Garment Apparel & 256 & 2 \\
\hline 11 & Vocational Proseccing & 176 & 2 \\
\hline 12 & Vocational Tourism & 96 & 2 \\
\hline & & 1920 & 22 \\
\hline
\end{tabular}

Source: BLK Banda Aceh, 2020

BLK Banda Aceh currently has 48 employees, with different groups. In connection with the religion that is embraced by BLK Banda Aceh employees, most of them are 
Muslims, as many as 47 people, and only 1 person who is Christian. For more details about gender, BLK Banda Aceh employees can be seen in each of the following tables.

Table 3. Number of Employees of BLK Banda Aceh in 2020

\begin{tabular}{|l|c|c|c|}
\hline No & Employee Gender & Total & Percentage (\%) \\
\hline 1 & Male & 32 & $68,08 \%$ \\
\hline 2 & Female & 16 & $32,92 \%$ \\
\hline & & 48 & $100 \%$ \\
\hline
\end{tabular}

Source: BLK Banda Aceh, 2020

While relating to the education level of BLK Banda Aceh employees, they vary greatly in levels and levels, even none with S3-level education. For more details about the education level of Banda Aceh BLK employees, see table below.

Table 4. Level of Education of BLK Banda Aceh Employees in 2020

\begin{tabular}{|l|l|c|}
\hline No & Level of education & Total \\
\hline 1 & SD or equivalent & 1 \\
\hline 2 & Junior High School or equivalent & - \\
\hline 3 & High school equivalent & 3 \\
\hline 4 & D3 & 8 \\
\hline 5 & SI & 29 \\
\hline 6 & S2 & 7 \\
\hline 7 & S3 & - \\
\hline & \multicolumn{2}{|c|}{ Total } \\
\hline
\end{tabular}

Source: BLK Banda Aceh, 2020

Regarding the BLK Banda Aceh employee group, most of them are in group III, while the number of BLK Banda Aceh employees who are group II and IV are still very small. For more details about the BLK Banda Aceh employee class, it can be seen in table below.

Table 5. Employee Group BLK Banda Aceh in 2020

\begin{tabular}{|l|c|c|}
\hline No & BLK Employee Group & Total \\
\hline 1 & IV/e & - \\
\hline 2 & IV/c & - \\
\hline 3 & IV/b & 2 \\
\hline 4 & IV/a & 8 \\
\hline 5 & III/d & 12 \\
\hline 6 & III/c & 10 \\
\hline 7 & III/b & 7 \\
\hline 8 & III/a & 5 \\
\hline 9 & II/d & 3 \\
\hline 10 & II/b & 48 \\
\hline & Total & \\
\hline
\end{tabular}

Source: BLK Banda Aceh, 2020

The results showed that the amount of work carried out by BLK employees was actually very large, considering the large number of community members who participated in 
various trainings to gain expertise, especially when participants registered to become participants in each year on average more than one thousand eight hundred people. Participants sometimes come to register for training collectively and do not confirm before registering.

The results of work carried out by BLK Banda Aceh employees start from the process of managing incoming letters, both of a normal nature and confidential incoming letters, to the stage of managing outgoing letters and facilitating various activities that become part of the annual program at Work Training Center (BLK) in Banda Aceh. Based on the results of interviews that researchers have conducted with several informants and coupled with the results of observations and study of documents at Work Training Center (BLK), it can be concluded the research "BLK Banda Aceh has employees who have the quality in completing various tasks assigned to him, even so it remains improvement is needed both through training, seminars and through improving education ".

Oracci in services related to the attitudes and work behavior of employees in providing services to various parties served or who need services. The services provided especially to the community are given equally by the employees of Work Training Center (BLK) without picking on the people who need services. The results of the study showed that the behavior of BLK employees was very good, especially related to integrity owned by berointasi on values, norms and ethics in daily life in carrying out the duties that are its obligations "

\section{Conclusion}

Based on the description of the results of research and discussion above, it can be concluded as follows:

1. Employee Work Targets at Work Training Center (BLK) in Banda Aceh both related to quantity, quality, time and cost indicate that the quantity of work is very large and does not reduce quality. While the time spent completing these activities varies greatly and depends on the program itself. In completing the activity there is a time needed for one day, there is also one week and also one month to take the time to complete the activity program at Work Training Center (BLK) in Banda Aceh. Furthermore, related to the costs required to complete a job, it really depends on the proposal and also a realistic study. So that the costs incurred are not the same as the proposed budget. This is due to the fact that realization is adjusted to cost efficiency.

2. Employee Behavior at Work Training Center (BLK) in Banda Aceh in conducting service orientation to the community and other parties by promoting equality, meaning that there is no difference in services provided to the community and also to other institutions. That is because BLK Banda Aceh employees maintain the inherent integrity of an employee. In carrying out the duties of their employees also commit to the work so as to carry out the work with full discipline. In its implementation, it also prioritizes cooperation among fellow employees which gives birth to the value of solidarity while also facilitating employees in completing various tasks together. In this case the existence of a leader has not been able to motivate the scientists, but does not also hamper the work of subordinates. 


\section{References}

Abidin, Said Zainal. (2014). Kebijakan Publik. Jakarta: Salemba Humanika.

Agustino. (2013). Efektifitas Kebijakan dalam konteks administrasi publik. Jakarta: Rineka Cipta.

Anggara, Sahya. (2014). Kebijakan Publik. Bandung: CV. Pustaka Setia.

Bangun, Wilson. (2014). Manajemen Sumber Daya Manusia. Bandung: Erlangga.

Bohlander, George., \& Snell, Scott. (2014). Principles of Human Resource. Management, 15th ed. Mason, OH: South Western-Cengage Learning.

Bungin, Burhan. (2014). Penelitian Kualitatif. Jakarta: Kencana Predana MediaGroup.

Dessler. (2013). Manajemen Sumber Daya Manusia Human Reources.Jakarta: Prenhalindo.

Faisal, Sanapiah. (2014). Format-Format Penelitian Sosial. Jakarta: Raja Grafindo Persada.

Griffiths, Ricky W dan Ebert, Ronald J. (2014). Bisnis. Jakarta: Erlangga.

Hamzah, Utami. (2013). Pendekatan Kualitatif Bagi Peneliti Pemula. Jakarta: PT Raja Grafindo Persada.

Hasibuan, Malayu S.P. (2013). Manajemen Sumber Daya Manusia, Edisi Revisi. Jakarta: Bumi Aksara.

Mangkunegara, Anwar Prabu. (2013). Manajemen Sumber Daya ManusiaPerusahaan. Bandung: Remaja Rosda Karya.

Moleong, Lexy J. (2014). Metode Penelitian Kualitatif. Bandung: PT Remaja Rosdakarya.

Mulyana, Dedy. (2014). Metodologi Penelitian Kualitatif Paradigma Baru Ilmu Komunikasi Dan Ilmu Sosial Lainnya. Bandung: Remaja Rosdakarya.

Musanef. (2016). Memahami Good Governance. Yogyakarta: Gava Media.

Nugroho, Riant. (2016). Public Policy. Jakarta: Gramedia.

Rivai, Veithzal. (2014). Kepemimpinan dan Perilaku Organisasi. Edisi ke Empat. Jakarta: PT. Raja Grafindo Persada.

Simamora, Henry. (2014). Manajemen Sumber Daya Manusia. Yogyakarta: STIE YKPN.

Sugiyono. (2016). Metode Penelitian Kualitatif. Bandung: Alfabeta.

Sulistiyani, A.T. dan Rosida. (2013). Manajemen Sumber Daya Manusia: Konsep, Teori dan Pengembangan dalam Konteks Organisasi Publik. Yogyakarta: Garaha Ilmu.

Tatang, Suherman. (2014). Metodologi Penelitian Kualitatif. Jakarta: PT Raja Grafindo Persada.

Thoha, Miftah. (2014). Birokrasi Pemeritahan Indonesi di Era Reformasi. Yogyakarta: Media Widya Mandala.

Torang, Syamsir. (2014). Organisasi dan Manajemen (Perilaku, Struktur, Budaya, \& Perubahan Organisasi). Bandung: CV. Alfabeta.

Usman, Budiman. (2014). Sistem Administrasi Pemerintahan Daerah. Jakarta: Bumi Aksara. 